\title{
GUARANTEED EMPLOYMENT PLANS
}

\author{
R. L. HiBBARD*
}

The mere mention of guaranteed employment is likely to excite widespread interest and support from those persons and groups who desire, through the enactment of state unemployment compensation laws, to prevent unemployment as well as to alleviate its effects. The very term "guaranteed employment" connotes an advance security which is not implied in connection with the standard (unemployment benefit) provisions of state laws.

Since guaranteed employment plans call for an advance guaranty of employment for a minimum number of hours per week and for a stated number of weeks per year, such plans immediately appeal as "job assurance" in contrast to "unemployment insurance." It is apparently with the purpose of providing for this socially attractive option that the Wisconsin, California, and Oregon laws contain provisions permitting guaranteed employment plans. ${ }^{1}$

Employer interest in such plans may be explained on two grounds, either of which may, depending on individual circumstances, play the dominant rôle: (I) Some employers will select guaranteed employment plans out of a definite desire to undertake a greater responsibility to their employees than is ordinarily required. Many such employers are, however, not unmindful of the fact that their employment picture is already such, by the nature of their business, that guaranteed employment will not prove particularly costly. (2) The merit rating assured by such plans may induce a few less stable employers to undertake the plan, but as a rule, only where alternative merit-rating plans are not available.

\section{Guaranteed Employment under the Social Security Act}

The American approach to guaranteed employment, as exemplified by the Social Security Act and by the state laws moulded to its pattern, differs essentially from that existing under the English system. In England a small group of employers have been "excepted" with respect to certain groups or classes of their employees who have been most steadily employed. Where an employer has a group of employees who have been employed in an employment classed as permanent and who have not lost

- B.A., I932, M.A., I933, University of Wisconsin. Unemployment Compensation Analyst for the State of Wisconsin. Contributor to business periodicals on unemployment compensation questions.

${ }^{1}$ WIs. STAт. \$108.15; Cal. Stat. 1935, c. 352, art. 3, \$41; Ore. Laws 1935, H. B. No. 71, \$\$2 (o), I6 (b). 
a single full day's wages for a period of three years, both the employer and his employees are relieved of contributions until either condition is broken, in which event contributions must be made until the record is reesstablished. There is no penalty other than this for failure to provide the required work, and the employee has no redress or benefits in the event of unemployment. The British system actually requires that a part of each employer's employees be "insured,"-in order to provide a cushion in slack times. ${ }^{2}$

The Social Security Act sets up a very different basis for guaranteed employment. Section 9I0, relating to the conditions for granting "additional credit" (without which no employer could be persuaded to try guaranteed employment), defines the term "guaranteed employment account" as follows:

(3) The term 'guaranteed employment account' means a separate account, in an unemployment fund, of contributions paid by an employer (or group of employers) who

(A) guarantees in advance thirty hours of wages for each of forty calendar weeks (or more, with one weekly hour deducted for each added week guaranteed) in twelve months, to all the individuals in his employ in one or more distinct establishments, except that any such individual's guaranty may commence after a probationary period (included within twelve or less consecutive calendar weeks), and

(B) gives security or assurance, satisfactory to the State agency, for the fulfillment of such guaranties,

from which accounts compensation shall be payable with respect to the unemployment of any such individual whose guaranty is not fulfilled or renewed and who is otherwise eligible for compensation under the State law."

Section gro further specifies that additional tax credits shall be allowed an employer-whose contribution rate has been reduced (under a state law permitting guaranteed employment accounts) because of the favorable record and status of his separate "guaranteed employment account"-only if the Social Security Board finds that under such law:

"(2) Such lower rate, with respect to contributions to a guaranteed employment account, is permitted only when his guaranty of employment was fulfilled in the preceding calendar year, and such guaranteed employment account amount to not less than $7 \frac{1}{2}$ per centum of the total wages payable by him, in accordance with such guaranty, with respect to employment in such State in the preceding calendar year;"

Under the foregoing federal standards, guaranteed employment plans must meet the following minimum requirements in order to qualify for "additional credit":

I. The guarantying employer must guarantee employment in advance to all his employees for at least 40 of the 52 weeks succeeding the guaranty date, and must furnish at least $3^{\circ}$ hours of employment in each guaranteed week (with one weekly hour deducted for each additional guaranteed week). The only exception to the universal guaranty is the preliminary "probationary service period" requirement.

${ }^{2}$ Cf. Hill and Lubin, The British Attack on Unemployment, Brookings Instuturion Pus. No. 51 (1934) 290-293. 
This is, of course, a most decided contrast to the English system, with its "cushion" of insured employees.

2. The guarantying employer is allowed additional credit for a lower rate only if his "guaranty of employment was fulfilled in the preceding calendar year." This statement leads one to wonder whether there can be any grounds which will justify non-fulfillment of guaranty under a state law-whether even misconduct or quitting by an employee would be so recognized.

3. The guarantying employer must pay benefits to every employee whose annual guaranty is fulfilled but not renewed, just as if he had no guaranteed employment plan but were directly complying with the standard provisions of his state law.

4. The guarantying employer must provide security satisfactory to the state agency. State requirements will undoubtedly vary considerably, but it is possible that a state may initially require heavy collateralization of a liability running to nearly one-half of the employer's annual payroll.

5. In addition to providing any security which may initially be required of him, he must currently contribute a percentage of his payroll to the state unemployment fund, until his contributions (in his guaranteed employment account) aggregate $7 \frac{1}{2}$ per cent of his annual payroll. In a state with straight employer reserve accounts, this means that a guarantying employer must meet substantially the same requirements as apply to all other employers. In a state where the employer with a guaranteed employment account is required to pay a fixed percentage to a pooled fund, the entire load of deficiency wage payments must be born by the guaranteed employment account despite the fact that it is receiving a lesser share of the employer's contributions. As a result, additional credit will often be so far postponed as to cease to be an incentive for stabilization.

\section{Wisconsin Experience with Guaranteed Employment}

The original Wisconsin law, as it went into effect in July, I934, did not require guarantying employers to contribute to an unemployment fund. In this way an advance merit-rating was provided, based on financial responsibility and employment experience. It might have been expected that large groups of moderately stable employers would try the plan under these advantageous conditions. But only 90 employers out of more than 4,000 subject to the act actually selected the plan. Of this number 3 terminated their plans by the end of the first guaranty year and possibly another 15 or more would have terminated their plans even if the law had not been amended to meet federal standards. As a result of the r935 amendments, not more than two or three Wisconsin employers will continue their plans.

The largest portion of the group which originally selected the guaranteed employment plan in Wisconsin consisted of insurance companies, banks, and hospitals, and a few mercantile establishments whose employment was already extremely stable. There were five manufacturing concerns in the group, three of which selected 
the plan because they believed their employment was stable, and the other two (paradoxically) because their employment was somewhat unstable. Due to the fact that the guaranty covered only 42 weeks per year under the early Wisconsin law, a long waiting period of ro weeks per year without benefit was available to these guarantying employers. In two of these cases there was an annual slack period of from eight to ten weeks, and the plan was considered to be less expensive than the benefit provisions of the law-which at that time allowed only two weeks of waiting period without benefits in 52 weeks.

When the Wisconsin law was amended to conform with the Social Security Act, it was necessary to require contributions from guarantying employers, so that this advance merit-rating feature disappeared. While this change was undoubtedly the immediate stimulus to abandonment of the plan in Wisconsin, there are other features inherent in any effective type of guaranteed employment plan, whether or not it meets these specific federal standards, which appear to be objectionable to the employer, to his employees, and to the administrative agency.

\section{Difficulties Inherent in Guaranteed Employment}

The guaranteed employment plan must apply to all an employer's employees, not only to meet the standards of the Social Security Act, but also to assure equal treatment to all employees. It is surprising how difficult it usually is to guaranty all one's employees on these terms. It appears that even the most stable employees have, to some extent, a problem of casual, substitute, or part-time workers. ${ }^{3}$

The probationary service period is not designed to cover this situation. It consists of whatever employment occurs within twelve consecutive calendar weeks starting with the employee's first week of employment, and any employee who starts work for a guarantying employer is immediately eligible for guaranty if he works again for that employer at any time after the expiration of twelve weeks. The only way of avoiding liability under the probationary provisions is by adopting a policy of never rehiring casual or substitute workers. This policy is neither attractive nor practical.

In regard to such temporary employment, the guaranteed employment plan is much less flexible than the benefit provisions of state laws. Benefits under state laws are paid for a period whose duration bears a definite ratio to the length of the employee's previous employment. A typical ratio is one-quarter week of benefits to each week of employment. Under these ratio provisions the employee who has been temporarily employed by an employer receives less in benefits chargeable against that employer, because he rendered his services over a shorter period than the regular employee.

${ }^{8}$ Another difficulty of the same type, but more involved in nature, arises where the guarantying $\mathrm{cm}$ ployer contracts out a part of his usual business from time to time. State laws generally treat the employees of such a contractor as the employees of the principal employer unless the contractor is himself subject to the state law. The diffieulties of guarantying employment to the employees of an independent contractor are obvious. 
On the other hand, employee rights under a guaranteed employment plan bear no logical relation to past services. If an employee happens to complete his probationary period, he is entitled to 40 weeks of employment, but if he works one week less as probationer, he is entitled to nothing. This inflexibility works harshly on both employer and employee-on the employer because he sometimes makes costly mistakes in his records or in his interpretation of his plan, and on the employee because his rights in comparison with his fellow workers are arbitrarily and sometimes fortuitously determined.

Guaranteed employment under a state law differs essentially from guaranteed employment plans worked out by private employers without reference to state laws, in that a private plan can be adapted to the employer's individual circumstances, if necessary by not protecting all employees. State standards for guaranteed employment must specify, in the interests of equal beneficiality, that every one of the employer's employees be entitled to receive unemployment compensation in the same circumstances in which he would be eligible under the standard provisions of the state law.

A few examples drawn from Wisconsin experience will serve to illustrate the characteristic inflexibility of such plans:

The 42 "guaranteed weeks" under the Wisconsin guaranteed employment plans were assumed to run consecutively from the guaranty date, unless the employee received advance notice that a given week would be treated as an "unguaranteed week." The desirability of this notice requirement (permitting the employee to seek other employment for an "unguaranteed week") is not questioned; but the practical affect of the requirement became obvious when some employers, who had actually given 42 out of 52 weeks employment, had to pay deficiency wages because they failed to give proper notice.

Individual guaranties must specify a definite guaranteed wage rate which can be changed only when the guaranty expires, since a mere work guaranty would have little meaning. Conceding that security of wage rate is desirable, there are circumstances in which many employers feel that a reduction in wage rates is an immediate and absolute necessity. Guaranteed wage rates, fixed at different times for different individuals, might appear undesirable to organized labor in connection with its bargaining activities. Further difficulty arises in connection with those employers, a part of whose staff is paid on a fluctuating commission or piece rate basis. In these cases, where frequent changes in commission or piece rates occur, computations of the equivalency of the new rates become extremely complicated, involving an averaging of employee earnings at the old and new rates and the application of the ratio between such averages to each employee's hourly earnings in order to determine the deficiency wage.

Finally, many employers have been and will continue to be deterred from using guaranteed employment plans because there is no limit to their potential liability 
under such plans. Under the standard provisions of every state law the employer's liability is limited to the amount of his contribution payments. In general, from the employer's point of view the guaranteed employment plan is highly cumbersome and technical-to the extent of requiring continuous executive attention. It may often result in unequal treatment of employees because of the emphasis which it places on arbitrary dates and on notice requirements in connection with their rights.

\section{Administrative Problems}

From an administrative point of view, the guaranteed employment plan also presents an unsatisfactory aspect, related to some extent to the same difficulties experienced by employers. One of the chief administrative objections to the plan is the fact that only a limited group of employers can and will make use of it. In Wisconsin only go out of more than 4000 employers selected the plan, and a material proportion of this group was finding the plan too expensive even before the recent r935 amendments. The expense of special rules, regulations, procedure, forms, and audits is a large fixed charge which an administrative agency can ill afford to bear on account of so small a group of employers.

The same technical and rigid nature of guaranteed employment referred to as a disadvantage to employers is a source of added administrative expense. The only satisfactory means of enforcement of guaranteed employment plans appears to be periodic intensive audits, involving an examination of the employment record of each individual employee for a period of 52 weeks. Wisconsin experience has shown that neither the self-interest of the employee nor the honesty of the employer is sufficient to overcome ignorance of the detailed provisions of the plan and to assume complete fulfillment of its terms. Field examinations of this sort are a highly expensive item, particularly since they must be far more intensive than an ordinary audit of payrolls. Under the benefit provisions of state laws detailed audits of this character should not be necessary, since employees can reasonably be expected to know what determines their rights and to file claim. In such event an audit of the employment record for the single claimant might occasionally be necessary, but hardly for all of an employer's employees.

\section{Conclusion}

In the light of the foregoing observations the present writer concludes that few states should attempt to provide for guaranteed employment plans. The only exception might be in the case of states not having effective merit rating, where it is desired to provide such merit rating for a strictly limited group of unusually stable employers. Guaranteed employment will never be widely adopted by employers in states having "reserves" laws or "pooled fund" laws with adequate and effective merit rating. Any guaranteed employment plan is apt to prove more complicated and in general less satisfactory than might appear at first glance. 